\title{
FEAR OF SUCCESS PEREMPUAN BEKERJA (dalam Perspektif Budaya Jawa)
}

\author{
Agustin Rahmawati, Suryanto, Nurul Hartini \\ Universitas Merdeka Malang, Universitas Airlangga Surabaya \\ Email:agustin.rahmawati@unmer.ac.id, suryanto@psikologi.unair.ac.id, \\ nurul.hartini@psikologi.unair.ac.id
}

\begin{abstract}
ABSTRAK
Ketakutan akan konsekuensi yang akan diterima jika keberhasilan diraih (Fear of Success /FOS) telah menjadikan perempuan enggan untuk berprestasi tidak terkecuali pada perempuan Jawa. Tulisan ini bertujuan untuk memberikan gambaran dinamika FOS pada perempuan Jawa. Menggunakan library research, penelitian ini menyimpulkan bahwa fear of success (FOS) bagi perempuan Jawa yang bekerja dilatar belakangi oleh budaya Jawa yang menempatkan perempuan sebagai kanca wingking bagi suami. Falsafat ini membuat konflik tersendiri bagi perempuan antara mengejar pencapaian prestasi dan penyesuaian diri atas nilai-nilai budaya di sekitarnya agar tetap bisa diterima. Namun demikian, dengan intervensi budaya yang tidak terelakkan, FOS masih bisa direduksi dengan memperhatikan faktor-faktor yang mempengaruhi. Dengan meningkatkan self esteem, selalu merasa optimis dengan kemungkinan-kemungkinan yang terjadi di masa datang, serta tetap berusaha positifterutama terhadap kultur yang ada, perempuan Jawa mampu mengaktualisasikan dirinya, meskipun tidak bisa dipungkiri FOS masih muncul dengan tingkat yang minimal.
\end{abstract}

Kata Kunci: Fear of Success, Perempuan Bekerja, Budaya Jawa 


\section{ABSTRACT}

Fear of consequences that will be accepted if success is achieved (Fear of Success /FOS) has made women reluctant to excel, including Javanese women. This paper aims to provide an overview of the FOS dynamics of Javanese women. Using the library research, this study concludes that fear of success (FOS) also occurs in Javanese female workers who have a Javanese cultural background that places women as kanca wingking (complementary). This philosophy made an inner conflict for women between pursuing achievement and adjusting themselves to the cultural values around them so that they could still be accepted. However, with inevitable cultural intervention, FOS can still be reduced by paying attention to the factors that influence it. By increasing self-esteem, always feeling optimistic about the possibilities that occur in the future, and still trying positively, especially on the existing culture, Javanese women are able to actualize themselves, although it is undeniable that FOS still appears with a minimal level

Keywords: Fear of Success, Working Female, Javanesse Culture

\section{A. Pendahuluan}

Jumlah penduduk perempuan Indonesia berdasar SUPAS 2015 (Survei Penduduk antar Sensus 2015) menunjukkan angka yang mendekati jumlah penduduk laki-laki. Dari 255,2 juta jiwa penduduk Indonesia secara keseluruhan, 126,9 juta diantaranya adalah perempuan, sedangkan penduduk laki-laki mencapai angka 128,2 juta (BPS, 2015). Dari hasil tersebut didapatkan data bahwa dari 100 penduduk perempuan, terdapat 101 penduduk laki-laki. Itu artinya rasio jumlah penduduk antara laki-laki dan perempuan relatif seimbang. Dengan jumlah tersebut, maka dapat dipahami jika pemerintah memberikan perhatian yang cukup besar terhadap potensi perempuan dalam pembangunan.

Meskipun pertumbuhan angkatan kerja perempuan lebih cepat daripada laju pertumbuhan angkatan kerja laki-laki, tetapi peningkatan tersebut tidak diikuti oleh keterlibatan perempuan sebagai pengambil keputusan, perumus kebijaksanaan maupun perencanaan pembangunan di segala tingkatan.

Gerakan kaum perempuan sendiri di Indonesia sudah dimulai jauh sebelum kemerdekaan RI di proklamirkan, yaitu oleh Kartini putri Bupati 
Jepara. Dengan diadakannya konferensi perempuan sedunia pertama oleh PBB pada tahun 1975, maka tahun itu dianggap sebagai tonggak sejarah penting dalam gerakan kaum perempuan di seluruh dunia. Setelahnya, pembicaraan tentang perempuan ditampung dalam CEDAW atau ICEDAW (International Convention on Elimination of All Forms of Discrimation Againts Women) atau Kesepakatan Hak Asasi Internasional yang secara khusus mengatur hak-hak perempuan. CEDAW ditetapkan oleh sidang umum PBB tanggal 18 Desember 1979 dan berlaku pada 3 September 1981. Pada bulan Juni 2007 tercatat 185 negara telah menandatangani konvensi ini. Konvensi ini juga bicara tentang penghapusan segala bentuk diskriminasi terhadap perempuan, dimana Indonesia menjadi salah satu negara yang ikut menandatangani. Itu artinya bahwa perbincangan dan pembahasan tentang kesetaraan gender antara laki-laki dan perempuan akan semakin terbuka, termasuk juga tentang peluang yang sama untuk berpartisipasi dalam proses pembangunan di segala lini kehidupan. Namun pada kenyataannya, hal itu masih jauh dari yang diharapkan (Lubis, 2004).

Peran perempuan terlihat masih sangat kurang dalam bidang pendidikan khususnya di perguruan tinggi. Seperti halnya di beberapa perguruan tinggi lain, data mengenai jumlah guru besar di Universitas Airlangga Surabaya menunjukkan kesenjangan yang cukup signifikan antara laki-laki dan perempuan. Dari 177 orang guru besar, 125 diantaranya lakilaki, dan hanya 52 perempuan (Direktorat Sumber Daya Manusia Universitas Airlangga, 2016).

Dalam kancah politik, peran perempuan Indonesia saat ini masih jauh dari yang diharapkan, karena sampai saat ini masih berada di tepi lingkaran arena dunia politik, dan belum masuk ke dalamnya (Lubis, 2004), meskipun perbincangan tentang perempuan di parlemen kian hari kian menguat. Rendahnya keterwakilan perempuan di DPR dan eksekutif tidak hanya terjadi di tingkat pusat saja, melainkan sampai DPRD I, DPRD II, dan lembaga eksekutif maupun yudikatif.

Dari Publikasi Statistik Indonesia 2015 tentang anggota DPR menurut jenis kelamin, didapatkan data bahwa dari 560 orang anggota secara keseluruhan pada periode 2014-2019, terdapat 97 orang anggota perempuan 
atau $17 \%$, dan 463 orang laki-laki. Sementara pada periode sebelumnya 2009-2014 terdapat 103 orang anggota perempuan dari 560 anggota secara keseluruhan (BPS, 2015) atau $18 \%$, sehingga dapat dikatakan bahwa keterwakilan perempuan sangat timpang dibanding laki-laki.

Ketimpangan yang sangat mencolok tersebut tidak hanya terjadi pada kancah legislatif, tetapi hampir pada semua aspek kehidupan politik. Seperti misalnya peran perempuan di Mahkamah Agung (MA) dan Mahkamah Konstitusi (MK) atau untuk jabatan sebagai Duta Besar. Sementara pada kancah eksekutif, meskipun sekarang sudah mulai merambah Kepala Daerah perempuan, pada kenyataannya masih sangat sedikit jika dibandingkan dengan jumlah Kepala Daerah laki-laki.

Sementara itu, sampai dengan tahun 2012 meskipun formasi perempuan pegawai negeri sipil (PNS) semakin meningkat dari tahun ke tahun, tetapi untuk formasi pejabat struktural dalam keterkaitannya sebagai pembuat keputusan, menunjukkan persentasi yang masih jauh dari peran PNS laki-laki, yaitu 28,39\% untuk perempuan, dan selebihnya 76,61\% untuk laki-laki (BPS, 2013).

Data di atas menunjuk keterlibatan perempuan masih sangat sedikit dalam tatanan pengambil keputusan atau manajerial. Menurut para ahli, hal ini disebabkan karena aspirasi dan motivasi berprestasi perempuan masih sering diwarnai faktor-faktor sosial budaya (Jackaway \& Teevan, 1976; Zuckerman, et.al, 1980; Lawrence, 2006), dan karena di dalam masyarakat masih ada paradoks antara de yure dan de facto tentang kedudukan perempuan. Paradoks kedudukan perempuan dan tuntutan sosial budaya terhadap kaum perempuan untuk selalu bersikap dan berperilaku yang berpusat pada keluarga inilah yang sering menimbulkan konflik pada diri perempuan yang berkarir, yaitu konflik antara ideal budaya (cultural ideal) dan perempuan sebagai sumber daya manusia (Karpicke, 1980; Suratijah, 1991, dalam Sahrah, 2011). Dari studi yang dilakukan oleh Olsen dan Willemsen (1978), perempuan yang terhalangi dalam pencapaian prestasinya lebih disebabkan karena harapan kultural yang berkembang di masyarakat, sementara penelitian-penelitian lainnya (Zuckerman, et.al, 1980; Lawrence, 2006) mengatakan bahwa fear of success terbentuk dari faktor kepribadian dan budaya. Secara umum budaya 
masyarakat di dunia menempatkan laki-laki pada hierarki teratas, sedangkan perempuan menjadi nomor dua. Edward B. Taylor (dalam Koentjaraningrat, 1990) mengungkapkan bahwa kebudayaan merupakan keseluruhan yang kompleks, yang didalamnya terkandung pengetahuan, kepercayaan, kesenian, moral, hukum, adat istiadat, dan kemampuan-kemampuan lain yang didapat seseorang sebagai anggota masyarakat.

Perempuan Jawa, sebagai bagian dari perempuan pada umumnya di Indonesia masih terikat oleh adanya nilai-nilai budaya yang melekat dalam masyarakat tradisional, dalam hal ini adalah nilai-nilai budaya Jawa (Handayani \& Novianto, 2004). Adanya paham yang memberikan perspektif bahwa peran perempuan adalah untuk melayani, mengurus serta bertangggungjawab dalam urusan keluarga (macak, manak dan masak), sedangkan laki-laki diberi tugas sebagai sumber nafkah yang utama dan bertanggungjawab terhadap kebutuhan keluarga telah mengakibatkan terjadinya pembagian tugas di sektor domestik yaitu didalam kehidupan rumah tangga dan sektor publik yaitu diluar kehidupan rumah tangga. Sistem budaya patriarki inilah yang kemudian diduga dapat mendorong munculnya fear of success pada perempuan, terutama pada perempuan Jawa (Ningrum, 2006; Realyta, 2007). Hal itu dapat dimengerti karena dengan kesuksesannya, akan muncul kecemasan tersendiri bahwa dia akan ditolak masyarakat karena budaya yang berkembang kurang mengijinkan perempuan sukses di sektor publik.

Adanya konflik yang dirasakan perempuan untuk berkarir pada akhirnya membuat perempuan tersebut lebih memilih untuk menghindari sukses (Horner, 1972, dalam Wood \& Grenfeld, 1976; Hyde \& Kling, 2001; dan Sahrah, 2011). Motif menghindari sukses diidentifikasi sebagai suatu representasi psikologis dari stereotipe yang berkembang di masyarakat, bahwa kompetensi, kemandirian, kompetisi, dan prestasi intelektual adalah sebagai aspek yang inkonsisten dengan feminitas, dan lebih sesuai untuk karakter maskulin. Harapan untuk sukses diikuti oleh konsekuensi negatif terhadap kesuksesan itu sendiri, sehingga dapat menghalangi tingkat aspirasi (Horner, 1972), dengan demikian jika perempuan tersebut menerima kesuksesan, akan merasakan kecemasan, perasaan bersalah, merasa tidak feminin, dan 
mementingkan diri sendiri. Horner menyebut motif menghindari sukses ini sebagai fear of success (FOS) atau ketakutan akan sukses (Horner, 1972; Olsen \& Willemsen, 1978; dan Lentz, 1982). Menurut Horner (1970), feminitas dan prestasi adalah dua hal yang diinginkan individu, tetapi seringkali memunculkan konflik karena berjalan secara inkonsisten. Lebih jauh Horner mengatakan bahwa FOS akan muncul ketika individu mengantisipasi datangnya kesuksesan, sehingga pada akhirnya individu akan menghindari pencapaian prestasi (Lentz, 1982). Horner (dalam Sahrah, 2011) menegaskan bahwa fear of success adalah disposisi kepribadian yang menuntut individu untuk tidak melakukan suatu tugas dengan baik. FOS dimengerti sebagai suatu dimensi dari dinamika motivasi individu. Konsep ini mengatakan bahwa pada banyak orang terutama perempuan, memiliki motif menghindari sukses (motive to avoid success) lebih pada alasan terhadap konsekuensi dari kesuksesan tersebut yaitu penolakan sosial dan kehilangan feminitas (Lentz, 1982; Piedmont, 1988).

Penelitian-penelitian tentang fear of success yang dikaitkan dengan budaya telah banyak dilakukan, baik yang memisahkan diri dari aspek kepribadian (Olsen \& Willemsen, 1978), maupun yang menghasilkan temuan bahwa faktor kultural bersama-sama dengan kepribadian mempengaruhi fear of success (Jackaway \& Teevan, 1976; Schnitzer, 1977; Zuckerman, et.al, 1980; Lawrence, 2006). Dalam kajian ini, penulis mencoba membahas dari sisi budaya Jawa. Penelitian atau kajian tentang fear of success di Indonesia yang dikaitkan dengan budaya sudah pernah dilakukan, tetapi berbeda fokus, karena melihat perbedaan fear of success antara perempuan Jawa, Minang, dan Batak (Nauly, 2003). Artikel ini mengkaji secara khusus dinamika fear of success yang dialami oleh perempuan Jawa yang bekerja.

\section{B. Pembahasan}

\section{Domain Fear of Success}

Istilah fear of success (FOS) atau ketakutan akan sukses pertama kali diperkenalkan oleh Matina Horner pada tahun 1968 sebagai motive to avoid success atau motif untuk menghindari sukses. Motif menghindari sukses diidentifikasi sebagai sesuatu representasi psikologis dari stereotipe yang 
berkembang di masyarakat bahwa kompetensi, kemandirian, kompetisi, dan prestasi intelektual adalah sebagai aspek yang inkonsisten dengan feminitas, dan lebih sesuai untuk karakter maskulin (Horner, 1972). Temuan tersebut bermula dari penelitian Disertasi Doktor Matina S. Horner, di bawah bimbingan Prof. John Atkinson, yang dikenal dengan teorinya Expectancy Value sebagai bagian dari motivasi manusia. Horner banyak membahas tentang hubungan antara motif untuk menyelesaikan pekerjaan dengan kebutuhan untuk berprestasi (motivasi berprestasi), kebutuhan untuk berafiliasi, kebutuhan untuk perform, dan seberapa tinggi tingkat aspirasi untuk menyelesaikan tugas dengan sebaik-baiknya sebagai indikator keberhasilan (Tresemer, 1977).

Dalam penelitiannya, Horner menggunakan Thematic Apperception Test (TAT), yang diberlakukan pada partisipannya dengan jenis kelamin yang berbeda. Horner ingin melihat reaksi negatif atau positif partisipan terhadap kesuksesan seseorang yang dilihatnya dari TAT, dan menemukan bahwa $65 \%$ partisipan perempuan merespon negatif, lebih pada antisipasi terhadap konsekuensi negatif dari kesuksesan tersebut (Wood \& Grenfeld, 1976; Piedmont, 1988). Secara lebih mendalam, Horner berpendapat, pada umumnya perempuan beranggapan bahwa kesuksesan pada area tertentu (sebagai contoh akademik dan intelektual) menunjukkan sesuatu yang berlawanan dengan norma sosial, dan akan menghasilkan kritikan tersendiri secara sosial (Piedmont, 1988). Oleh karena itu, perempuan cenderung menghindari kesuksesan pada area dimana prestasi tersebut tidak konsisten atau bertentangan dengan feminitas (Horner, 1972).

Horner (dalam Lentz, 1982) menjelaskan bahwa FOS adalah suatu bentuk kecemasan atau ketegangan yang timbul akibat konflik yang dialami individu. Konflik ini muncul karena di satu sisi individu ingin berprestasi dan meraih kesuksesan, namun merasa cemas karena kesuksesan yang akan diraih diperkirakan dapat menimbulkan konsekuensi-konsekuensi yang tidak diharapkan. Sementara itu, dikatakan oleh Abbot (1992) bahwa FOS pada dasarnya bukan merupakan ketakutan akan pencapaian prestasi pada area yang secara stereotipe menjadi milik maskulinitas, tetapi lebih merupakan ketakutan pada konsekuensi-konsekuensi negatif yang muncul akibat 
kesuksesan yang akan diraihnya. Ditambahkan oleh Horner (1972), bahwa FOS seringkali tampak pada situasi prestatif dan kompetitif. Oleh karena itu, FOS lebih sering muncul pada perempuan di dalam situasi berprestasi yang kompetitif dibandingkan pada situasi bukan kompetitif, terutama bila harus berkompetisi dengan laki-laki. FOS lebih merupakan karakteristik dari perempuan yang memiliki orientasi berprestasi dan kemampuan yang tinggi. Pada perempuan dengan orientasi berprestasi rendah dan kemampuan kurang, kesuksesan merupakan sesuatu yang sulit untuk diraih dan bukan merupakan tujuan, sehingga mereka tidak mempermasalahkan tentang sukses (Lentz, 1982).

Menurut Shaw dan Costanzo (1982), ada tiga aspek FOS yaitu: (a). Loss of feminity atau ketakutan akan kehilangan feminitas, dalam hal ini, kehilangan feminitas diartikan sebagai hilangnya sifat keperempuanan dalam bentuk kekurangmampuan dalam menunjukkan sifat-sifat feminin, kekurangmampuan untuk menjadi istri dan ibu yang baik dan kurang dapat menjalankan peran sebagai perempuan dalam rumah tangga; (b). Loss of special self esteem atau ketakutan akan kehilangan penghargaan sosial. Hilangnya penghargaan sosial diartikan sebagai ketiadaan atau kurangnya penghargaan masyarakat terhadap diri perempuan yang sukses, karena ia tidak menampilkan sifat yang feminine; (c). Social rejection atau ketakutan akan penolakan sosial. Bentuk penolakan sosial ini kurang atau tidak diikutsertakannya perempuan sukses dalam kegiatan kelompok, kurang disenangi oleh teman-temannya baik laki-laki maupun perempuan. Berdasarkan uraian diatas dapat diartikan perempuan tersebut ditolak oleh lingkungan. Lebih lanjut Horner (dalam Lentz, 1982 dan Shaw \& Costanzo, 1982) menyimpulkan bahwa FOS tidak disadari oleh perempuan dan merupakan hasil dari proses sosialisasi yang spesifik pada perempuan. Proses sosialisasi ini mengarahkan perempuan terhadap antisipasi akan kehilangan feminitasnya (loss of feminimity). Kehilangan feminimitas ini mengarahkan perempuan untuk menjadi takut jika mendekati keberhasilan dan memperkirakan akan kehilangan penghargaan sosial (loss of self esteem) serta mengantisipasi adanya penolakan sosial (social rejection) yang diakibatkan oleh kesuksesannya. 
Sementara itu, Horner dan Walsh (dalam Rahmawati, 2005) mengatakan bahwa individu yang memiliki ketakutan akan sukses menunjukkan hasil kerja di bawah kemampuannya bila dihadapkan pada situasi kompetitif. Hal ini muncul dalam bentuk mengabaikan tugas yang harus diselesaikannya atau dengan kata lain tugas tersebut tidak diselesaikan dengan baik.

Ketakutan akan sukses dapat terlihat dari (a) adanya kecenderungan menjadi cemas atau ragu-ragu saat mendekati sukses (Horner, dalam Sahrah, 1996), (b) adanya antisipasi untuk menghindari kesuksesan dngan menarik atau menolak kesempatan meraih sukses. Penarikan diri ini dilakukan secara sadar, yaitu ketika kesuksesan akan segera dicapai, sehingga individu secara sadar mempersepsi kesuksesan tersebut sebagai suatu stimulus bahaya yang sedang mendekat, sehingga dilakukan tindakan-tindakan antisipasi untuk menghindarinya (Pappo, dalam Sahrah, 1996).

Adelson (dalam Rahmawati, 2005) menyatakan bahwa individu yang mengalami ketakutan akan sukses cenderung kurang memiliki usaha untuk menyelesaikan tugas dengan baik agar terhindar dari konsekuensi yang tidak diharapkan. Selain itu mereka juga akan menetapkan tujuan-tujuan yang mudah dicapai, dan mereka berusaha mencapai hanya pada tujuan tersebut. Sementara itu Krueger (1992) mengatakan bahwa individu yang menglami hambatan dalam meraih kesuksesan, dapat nyelesaikan pekerjaannya dengan baik selama hal tersebut masih berada pada jarak yang aman, namun setelah sukses tercapai akan timbul kecemasan dan berusaha untuk mengurangi kesuksesan tersebut.

\section{Faktor-faktor yang mempengaruhi Fear of Success}

Fear of success bukan sesuatu yang muncul dengan sendirinya. Banyak faktor yang diduga mempengaruhi munculnya fear of success pada perempuan. Pada penelitian yang dilakukan oleh Olsen \& Willemsen (1978) mengatakan bahwa fear of success tidak berkorelasi dengan variabel kepribadian tertentu, tetapi lebih pada hasil dari faktor kultural. Sementara pada banyak penelitian menghasilkan temuan bahwa fear of success adalah salah satu disposisi kepribadian yang terbentuk melalui hasil interaksi dengan kultural (Jackaway \& Teevan, 1976; Zuckerman, et.al, 1980; Lawrence, 2006). 
Penelitian yang dilakukan oleh Stanculescu (2013) menghasilkan temuan bahwa optimisme berkorelasi negatif dengan fear of success. Individu yang mengalami FOS digambarkan sebagai individu yang pesimis. Patton et.al (2004) menyatakan optimisme dianggap sebagai suatu pertimbangan yang memiliki kecenderungan dapat mempengaruhi perasaan, sikap, cara berpikir, dan perilaku seseorang dalam siatuasi tertentu. Tentang adanya kemungkinan konsekuensi negatif dari masyarakat terhadap kesuksesan yang diperoleh oleh perempuan, individu yang optimis akan dapat mengatasi kecemasan yang dialaminya dengan baik, karena optimisme sendiri berarti kecenderungan untuk memandang segala sesuatunya dari segi dan kondisi yang baik (Saphiro, 1997). Scheier dan Carver (2002) menjelaskan bahwa individu yang optimis adalah individu yang mengharapkan hal-hal yang baik terjadi pada mereka, sehingga individu tidak lagi berpikir tentang konsekuensi-konsekuensi negatif akibat dari kesuksesannya.

Faktor lain yang juga berkaitan dengan fear of success adalah self esteem (Kumari, 1995; Stanculescu, 2013; Petty, 1992), meskipun studi yang lain mengatakan bahwa tidak ada korelasi antara fear of success dengan self esteem (Barnet, 1991). Pada individu dengan fear of success yang tinggi ditunjukkan dengan tingkat self esteem yang rendah (Kumari, 1995, dan Stanculescu, 2013). Artinya, dengan memiliki penghargaan terhadap dirinya secara layak, akan meminimalkan munculnya fear of success. Menurut Coopersmith (1967), self esteem merupakan hasil evaluasi individu terhadap diri sendiri, evaluasi mencakup sikap penerimaan atau penolakan, dan menunjukkan seberapa besar individu percaya bahwa dirinya mampu, berarti, berhasil, berharga menurut standar pribadinya. Dengan pengertian diatas, dapat dimengerti bahwa individu dengan self esteem yang rendah akan merasakan dirinya kurang berharga, kurang percaya diri, kurang dicintai, sehingga dengan adanya tekanan-tekanan yang diterimanya dari masyarakat akibat kesuksesannya, akan menimbulkan rasa bersalah yang pada akhirnya akan lebih memacu individu untuk menghindari sukses.

Dari studi yang dilakukan oleh Olsen dan Willemsen (1978), perempuan yang terhalangi dalam pencapaian prestasinya lebih disebabkan karena harapan kultural yang berkembang di masyarakat, sementara 
penelitian-penelitian lainnya (Zuckerman, et.al, 1980; Lawrence, 2006) mengatakan bahwa fear of success terbentuk dari faktor kepribadian dan budaya. Secara umum budaya masyarakat di dunia menempatkan lakilaki pada hierarki teratas, sedangkan perempuan menjadi nomor dua. Edward B. Taylor (dalam Kuntjaraningrat, 1990) mengungkapkan bahwa kebudayaan merupakan keseluruhan yang kompleks, yang didalamnya terkandung pengetahuan, kepercayaan, kesenian, moral, hukum, adat istiadat, dan kemampuan-kemampuan lain yang didapat seseorang sebagai anggota masyarakat. Perempuan Jawa, sebagai bagian dari perempuan pada umumnya di Indonesia masih terikat oleh adanya nilai-nilai budaya yang melekat dalam masyarakat tradisional, dalam hal ini adalah nilai-nilai budaya Jawa (Handayani \& Novianto, 2004). Adanya paham yang memberikan perspektif bahwa peran perempuan adalah untuk melayani, mengurus serta bertangggungjawab dalam urusan keluarga (macak, manak dan masak), sedangkan laki-laki diberi tugas sebagai sumber nafkah yang utama dan bertanggungjawab terhadap kebutuhan keluarga telah mengakibatkan terjadinya pembagian tugas di sektor domestik yaitu didalam kehidupan rumah tangga dan sektor publik yaitu diluar kehidupan rumah tangga. Sistem budaya patriarki inilah yang kemudian diduga dapat mendorong munculnya fear of success pada perempuan, terutama pada perempuan Jawa. Hal itu dapat dimengerti karena dengan kesuksesannya, akan muncul kecemasan tersendiri bahwa dia akan ditolak masyarakat karena budaya yang berkembang kurang mengijinkan perempuan sukses di sektor publik. Sehingga tidak berlebihan jika seberapa besar perempuan menginternalisasi nilai-nilai budaya akan menentukan seberapa tinggi fear of success yang dialami.

Sementara itu penelitian yang dilakukan oleh Chaudry (1995) mengatakan bahwa wellbeing adalah sebagai salah satu faktor yang mempengaruhi fear of success. Dalam penelitian yang berjudul Study of marital adjustment role conflict fear of success general well being and life stress amongst working and non working married women ditemukan hasil bahwa terdapat korelasi negatif yang signifikan antara general wellbeing dengan fear of success pada perempuan tidak bekerja, tetapi tidak demikian pada perempuan yang bekerja. Perempuan tidak bekerja yang memiliki tingkat wellbeing rendah 
menunjukkan kepercayaan terhadap dirinya sendiri yang rendah, sehingga dapat memicu rendahnya FOS.

Subjective wellbeing, sebagai salah satu komponen dari general wellbeing, dimengerti sebagai suatu fenomena yang meliputi evaluasi kognitif dan emosional individu terhadap kehidupan mereka, seperti apa yang disebut orang awam sebagai kebahagiaan, ketentraman, berfungsi penuh, dan kepuasan hidup (Diener, Oishi \& Lucas, 2003, Vitterso \& Nilsen, 2002). Menurut Biswar-Diener, Diener dan Tamir (dalam Utami, 2012) subjective wellbeing didefinisikan sebagai evaluasi individu terhadap kehidupannya yang berkaitan dengan komponen kognitif dan emosional yang mencakup tiga komponen utama, yaitu banyaknya mengalami afek positif atau afek yang menyenangkan seperti kegembiraan, kelegaan hati, kasih sayang, sedikitnya mengalami afek negatif atau afek yang tidak menyenangkan seperti kemarahan, ketakutan, dan kesedihan, serta persepsi tentang kepuasan hidup.

\section{Fear Of Succes bagi Perempuan dalam Budaya Jawa}

Dalam lingkungan masyarakat Jawa, ada beberapa istilah yang diberikan kepada perempuan berdasarkan peran dan kedudukan mereka. Istilah-istilah itu bukanlah sekedar istilah, melainkan membawa konsekuensi ideologis tertentu bagi perempuan (Sukri \& Sofwan, 2001), antara lain wadon, wanita, estri, dan putri, tidak ada satupun yang mendudukkan kaum perempuan secara sejajar dengan laki-laki. Semua istilah tersebut memberikan beban tertentu bagi perempuan.

Karakter perempuan Jawa digambarkan sebagai bertutur kata halus, tenang, diam/kalem, tidak suka konflik, mementingkan harmoni, menjunjung tinggi nilai keluarga, mampu mengerti dan memahami orang lain, sopan, pengendalian diri tinggi/terkontrol, daya tahan untuk menderita tinggi, memegang peranan secara ekonomi, dan setia/loyalitas tinggi (Handayani dan Novianto 2004). Sementara itu, Ronggowarsito dalam Handayani dan Novianto (2004) megatakan bahwa dalam kehidupan perempuan Jawa sering kita dengar istilah masak, macak, manakyang artinya pandai memasak, pandai berdandan atau bersolek, dan bisa memberi keturunannya. 
Di kalangan masyarakat Jawa, perempuan dikenal dengan istilah konco wingking untuk menyebut istri, hal itu menunjukkan perempuan tempatnya bukan di depan sejajar dengan laki-laki, melainkan di belakang, di dapur karena dalam konsep budaya Jawa wilayah kegiatan istri adalah seputar dapur, sumur, dan kasur. Hal itu menunjukkan sempitnya ruang gerak dan pemikiran perempuan sehingga perempuan tidak memiliki cakrawala di luar tugastugas domestiknya (Sukri \& Sofwan, 2001). Walaupun demikian, ikatan dan konsepsi wanita sebagai kanca wingking berlaku sebagai kondisi sak prayoganipun (seyogyanya) atau ideal bagi budaya Jawa. Tampaknya, ikatan aturan dan ikatan tersebut hanya berkembang dalam arena publik orang Jawa. Jadi secara publik atau formal baik berdasarkan persepsi laki-laki ataupun wanita Jawa sendiri, ide tentang wanita tetap "subordinat" atau derajat wanita dipandang lebih rendah daripada laki-laki.

Konsep perempuan Jawa yang lain tertuang dalam Serat Candrarini (Murniati, dalam Budiati, 2012) yang dapat dirinci menjadi antara lain ada beberapa butir:1). setia pada laki-laki, 2). rela dimadu, 3). mencintai sesama, 4). menguasai pekerjaan perempuan, 5). pandai berdandan dan merawat diri, 6). sederhana, 7). pandai melayani laki-laki, 8). menaruh perhatian pada mertua, 9). gemar membaca buku tentang nasehat bagi perempuan.

Seperti yang sudah dijelaskan diatas, bahwa fear of success lebih disebabkan karena faktor budaya. Budaya Jawa, sebagai bagian yang cukup dominan dari keseluruhan budaya Indonesia, dianggap telah menyumbang peran dalam menghambat tingkat aspirasi maupun prestasi perempuan.

Upaya meningkatkan pengetahuan dan prestasi perempuan Jawa, salah satunya dilakukan oleh Kartini. Pada mulanya, sekolah hanya khusus untuk orang Belanda dan juga bangsawan pribumi. Pembatasan akses ke sekolah itu secara mental memberikan makna bagi sekolah dalam struktur sekolah Jawa. Perempuan baru boleh masuk sekolah pada awal abad 20. Tetapi yang perlu dipertimbangkan adalah bahwa kesempatan itu tidak bergeser untuk memajukan perempuan sebagaimana pengertian pendidikan di Barat. Artinya, sekolah tidak difungsikan secara sosial sebagai alat untuk membuat perempuan bisa duduk pada meja yang sama 
dengan laki-laki, melainkan semata-mata dipahami sebagai suatu ruang yang berbeda dari ruang rumah tangga (Permanadeli, 2015). Sebagaimana kutipan dari Kartini:

"Jika kita meminta pendidikan dan pengajaran untuk anak perempuan, itu bukan dimaksud untuk membuat mereka menjadi saingan bagi laki-laki, tetapi agar perempuan mampu melakukan tugas besar yang diberikan kepadanya oleh Ibu Alam; ibu adalah pendidik pertama, ibu adalah pusat keluarga dan dia bertanggungjawab untuk memelihara anaknya bagi keluarga besar, sebab suatu hari anak itu akan menjadi bagian dari keluarga besar itu, dan bagian dari keluarga yang lebih besar lagi, yaitu masyarakat. Dengan maksud itulah kita meminta pendidikan dan pengajaran bagi anak perempuan."

Kutipan diatas seakan mendukung pendapat bahwa perempuan Jawa adalah kanca wingking, karena tempatnya bukan di depan sejajar dengan laki-laki, tetapi di belakang, di dapur karena dalam konsep budaya Jawa wilayah kegiatan istri adalah seputar dapur, sumur, dan kasur. Jika ada yang melanggar tata aturan yang berlaku, maka harus bersiap menerima sangsi dari masyarakat. Paradoks kedudukan perempuan dan tuntutan sosial budaya terhadap kaum perempuan untuk selalu bersikap dan berperilaku yang berpusat pada keluarga inilah yang sering menimbulkan konflik pada diri perempuan yang berkarir, yaitu konflik antara ideal budaya (cultural ideal) dan perempuan sebagai sumber daya manusia (Karpicke, 1980; Suratijah, 1991, dalam Sahrah, 2011).

Perempuan masih dianggap the second class yang keberadaannya tidak begitu diperhitungkan. Implikasidari konsep dan common sense tentang pemosisian yang tidak seimbangtelah menjadi kekuatan di dalam pemisahan sektor kehidupan ke dalam sektordomestik dan sektor publik di mana perempuan dianggap orangyang berkiprah dalam sektor domestik sementara laki-laki ditempatkan dalamsektor publik. Ideologi semacam ini telah disahkan oleh berbagai pranatadan lembaga sosial, yang ini kemudian menjadi fakta sosial tentang status dan peran yang dimainkan oleh perempuan (Abdullah, 1997).

Pranata dan stereotip seperti yang diatas inilah yang menjadikan perempuan enggan untuk mengembangkan potensinya, sehingga pada 
akhirnya akan menghambat kesuksesannya. Adanya ketakutan pada konsekuensi yang akan diterima jika kesuksesan diraih, tampaknya menjadi alasan yang paling kuat dalam menghambat aktualisasi diri perempuan, terutama perempuan Jawa. Seperti yang sudah disinggung oleh Shaw dan Constanzo (1982), perempuan menjadi takut sukses karena tiga hal, takut kehilangan feminitas, takut kehilangan penghargaan sosial, serta takut terjadi penolakan sosial. Takut kehilangan feminitas sangat dapat dimengerti karena stereotipe yang berkembang di masyarakat Jawa, bahwa kompetensi, kemandirian, kompetisi, dan prestasi intelektual adalah aspek yang inkonsisten dengan feminitas, dan lebih sesuai untuk karakter maskulin (Horner, 1976). Kehilangan feminitas ini bagi perempuan Jawa berarti tidak mampu menerapkan konsep manak, masak, dan macak- mengarahkan perempuan Jawa untuk menjadi takut jika mendekati keberhasilan dan memperkirakan akan kehilangan penghargaan sosial serta mengantisipasi adanya penolakan sosial akibat dari kesuksesannya tersebut.

Seperti juga yang sudah disinggung, Horner (dalam Lentz, 1982) menjelaskan bahwa FOS adalah suatu bentuk kecemasan atau ketegangan yang timbul akibat konflik yang dialami individu. Adanya konflik yang dirasakan perempuan Jawa dalam berkarir pada akhirnya membuat perempuan tersebut untuk lebih memilih menghindari sukses (Sahrah, 2011).

Pun demikian yang terjadi pada perempuan Jawa yang memiliki kesempatan untuk mengenyam pendidikan lebih tinggi. Permanadeli (2015) menyebutkan bahwa kerja dan rumah tangga bukan dunia yang saling berlawanan. Keterlibatan perempuan bekerja pada masa modern dalam kehidupan sehari-hari tidak membuat mereka dijauhkan dari sistem kultural yang membuat perempuan harus memikul tanggungjawab dan harus menata waktu dengan lebih baik untuk seluruh gerak keperempuanan yang dia ikuti. Lebih lanjut Permanadeli (2015) mengatakan bahwa dalam skema ini, bersekolah tidak berarti mengayunkan langkah menuju kebebasan perempuan dan dengan sendirinya bukan pula menuju kemerdekaan individual. Dengan demikian, tingkat pendidikan dan pekerjaanlah yang menjabarkan tempat perempuan Jawa dalam masyarakat (Mulder, 1996). Perempuan Jawa yang tergolong memiliki status sosial tinggi umumnya 
memiliki tingkat pendidikan tinggi pula dan berhasil dalam karier. Akan tetapi tetap saja mereka memiliki konsepsi tentang tempat perempuan yang sama dengan konsepsi yang dimiliki oleh perempuan yang berasal dari kelas sosial lainnya yang beranggapan bahwa tempat utama perempuan adalah rumah tangga.

FOS bagi perempuan Jawa disebabkan oleh aspek kultural sebagai penentu, tinggi rendahnya fear of success juga dipengaruhi oleh beberapa faktor, antara lain self-esteem, optimisme, dan wellbeing. Dengan memiliki penghargaan terhadap dirinya secara layak, akan meminimalkan munculnya fear of success. Dalam artian bahwa individu dengan self esteem yang rendah akan merasakan dirinya kurang berharga, kurang percaya diri, kurang dicintai, sehingga dengan adanya tekanan-tekanan yang diterimanya dari masyarakat akibat kesuksesannya, akan menimbulkan rasa bersalah yang pada akhirnya akan lebih memacu individu untuk menghindari sukses. Selanjutnya, individu yang optimis akan dapat mengatasi kecemasan yang dialaminya dengan baik, karena optimisme sendiri berarti kecenderungan untuk memandang segala sesuatunya dari segi dan kondisi yang baik.Individu yang optimis adalah individu yang mengharapkan hal-hal yang baik terjadi pada mereka, sehingga individu tidak lagi berpikir tentang konsekuensi-konsekuensi negatif akibat dari kesuksesannya. Yang terakhir, individu yang befungsi penuh, puas dengan kehidupannya, merasa bahagia dan memiliki kesejahteraan, akan dapat mengatasi ketakutan dan kecemasan-kecemasan yang dialaminya, termasuk ketakutannya terhadap kesuksesan. Dengan demikian, melalui faktor-faktor tersebut diatas, diharapkan dapat mereduksi munculnya fear of success pada perempuan Jawa. Tentu saja, masih banyak faktor dan aspek lain yang berperan dalam tinggi rendahnya fear of success.

\section{Simpulan}

Fear of success pada dasarnya bukan merupakan ketakutan akan pencapaian pada area yang secara stereotipe menjadi milik maskulinitas, tetapi lebih merupakan ketakutan pada konsekuensi-konsekuensi negatif yang muncul akibat kesuksesan yang akan diraih individu, terutama pada perempuan Jawa. Perempuan Jawa, dengan serangkaian pranata dan stereotipe 
yang berkembang pada masyarakat Jawa, dituntut untuk selalu berperilaku yang berpusat pada keluarga, sehingga seringkali muncul konflik pada diri perempuan, yaitu konflik antara ideal budaya dan perempuan sebagai sumber daya manusia. Pada pandangan yang lebih modern, fear of success perempuan Jawa dapat direduksi melalui serangkaian faktor yang terkait.

Individu yang optimis akan dapat mengatasi kecemasan yang dialaminya dengan baik, karena optimisme sendiri berarti kecenderungan untuk memandang segala sesuatunya dari segi dan kondisi yang baik. Individu yang optimis adalah individu yang mengharapkan hal-hal yang baik terjadi pada mereka, sehingga individu tidak lagi berpikir tentang konsekuensikonsekuensi negatif akibat dari kesuksesannya. Yang terakhir, individu yang befungsi penuh, puas dengan kehidupannya, merasa bahagia dan memiliki kesejahteraan, akan dapat mengatasi ketakutan dan kecemasan-kecemasan yang dialaminya, termasuk ketakutannya terhadap kesuksesan. Dengan demikian, melalui faktor-faktor tersebut diatas, diharapkan dapat mereduksi munculnya fear of success pada perempuan Jawa.

\section{DAFTAR PUSTAKA}

Abbot, M.R., 1992, Masculine and Feminine; Gender Roles Over The Life Cycle (second edition). New York: McGraw-Hill, Inc.

Badan Pusat Statistik \& Kementerian Pemberdayaan Perempuan dan Perlindungan Anak, 2013, Pembangunan Manusia Berbasis Gender. BPS Indonesia

Badan Pusat Statistik, 2015, Penduduk Indonesia; Hasil Survei Penduduk Antar Sensus 2015, BPS Indonesia

Barnet, D.L., 1991, “Fear of Success" Dissertation. Fort Hays State University 
Budiati, A.C., 2012, "Aktualisasi Diri Perempuan dalam Sistem Budaya Jawa” dalam Dilema (Dialektika Masyarakat)-Jurnal Sosiologi. Vol.29(1). 1322

Chaudry, M., 1995. Study of Marital Adjustment Role Conflict Fear of Success General Wellbeing and Life Stress amongst Working ang Nonworking Married Women,Thesis. tersedia dalam Shodganga Inflibnet, Panjab University

Coopersmith, S.,1967. The Antecendent of Self-esteem. San fransisco: W. H. Freeman and Company

Diener, E., Oishi, S., \& Lucas, R.E, 2003, "Personality Culture, and Subjective Well- Being: Emotional and Cognitive Evaluation of Life" dalam Annual Review of Psychology Vol. 54, 403 - 425.

Handayani, C.S. \& Novianto, A., 2004. Kuasa Wanita Jawa. LKiS. Yogyakarta

Horner, M.S., 1970, "Feminity and Successful Achievement: A Basic Inconsistency" dalam Feminine Personality and Conflict. Belmont, C.C.: Brooks/Cole Publishing Company

Horner, M.S., 1972, “Toward an Understanding of Achievement related Conflict in Women” dalam Journal Social Issues Vol. 28 No. 2 p. 157-175

Hyde, J.S. \& Kling, K.C., 2001, "Women, Motivation, and Achievement" dalam Psychology of Women Quarterly Vol. 25 p.364-378

Jackaway, R \& Teevan, R., 1976, "Fear of Failure and Fear of Success; Two dimensions of the same motive" dalam Sex Roles Vol. 2 No.3, p. 283293

Karpicke, S., 1980. "Perceived and Real Sex Differences in College Student's Career Planning” dalam Journal of Psychology. Vol. 44. 802-805.

Koentjraningrat, 1990, Pengantar Ilmu Antropologi. Rinema Cipta: Jakarta

Kumari, R., 1995, "Relationship of Sex Role and Self-esteem to Fear of Success among College Women' dalam Psychological Studies, Vol 40 No. 2 Jul 1995, 82-86

Krueger, D.W., 1993, Success and The Fear of Success in Women; A Developmental and Psychodynamic Perspective.

Lawrence, J., 2006, "Discussion of Nurturance and Self-Sabotage: 
Psychoanalytic Perspectives on Women's Fear of Success by Ellen G. Ruderman dalam International Forum of Psychoanalysis Vol. 15, 86-98

Lentz, M.E., 1982, "Fear of Success as a Situastional Phenomenon” dalam Sex Roles, Vol. 8, (9), 987-997

Lubis, T.M., 2004, “Persoalan Hak-hak Asasi kaum Perempuan” dalam Pembangunan Politik, Situasi Global, dan Hak Asasi di Indonesia. Jakarta; PT Gramedia

Mulder, N., 1996, “Inside Indonesia Society Cultural Change in Java” 2nd Ed., Amsterdam-Kuala Lumpur. The Pepin Press

Nauly, M., 2003, Fear of Success Wanita Bekerja (Studi Banding Perempuan Batak, Minangkabau, dan Jawa. Yogyakarta: ARTI

Olsen, N.J. \& Willemsen, E.W., 1978, "Fear of Success; Fact or Artifact?" dalam Journal of Psychology Vol. 98 65-70

Permanadeli, R., 2015, Dadi Wong Wadon; Representasi Sosial Perempuan Jawa di Era Modern, Yogyakarta: Pustaka Ifada-Rifka Annisa

Petty, R., 1992, “Fear of Success” Dissertation. Fort Hays State University

Piedmont, R.L., 1988. An Interactional Model of Achievement Motivation and Fear of Success. Sex Roles, Vol. 19(7/8), p. 467-490

Rahmawati, A., 2009, "Konsep Diri, Persepsi tentang Peran Ganda Ibu Bekerja, dan Ketakutan akan Sukses Remaja Perempuan di Sekolah Koedukasi dan Non-Koedukasi” dalam Jurnal Psikologi Tabularasa Vol. 4 No. 1 164-176

Sahrah, A., 1996, “Takut Sukses Wanita Karier; Tinjauan dari Segi Peran Jenis, Status Identitas Diri, dan Atribusi Kesuksesan” dalam Disertasi. Yogyakarta: Fakultas Psikologi UGM (tidak diterbitkan)

Sahrah, A.,2011, "Pengaruh Atribusi Kesuksesan terhadap Ketakutan akan Sukses pada Wanita Karir” dalam Jurnal Psycho Idea. Th. 9 No. 2, Juli 2011 ISSN 1693-1076

Saphiro, L.E., 1997, Mengajarkan emotional intellegence pada anak. Jakarta: PT. Gramedia, Pustaka Utama

Scheier, M.F. \& Carver, C.S., 2002, “Optimism” dalam In C.R. Snyder \& Shane J. Lopez. Handbook of Positive Psychology. New York: Oxford 
University Pres

Shaw, M.E., \& Constanzo, P.R., Theories of Social Psychology, Tokyo: McGrawHill, Inc.

Stanculescu, E., 2013, “University Students' Fear of Success from the Perspective of Positive Psychology" dalam Procedia-Social and Behavioral Sciences Vol. 78. 728-732

Sukri, S.S., \&Ridin Sofwan., 2001, Perempuan dan Seksualitas dalam Tradisi Jawa, Yogyakarta:Gama Media

Tresemer, D.W., 1977. Fear of Success. Plenum Press. New York

Utami, M.S., 2012, "Religiusitas, Koping Religius, dan Kesejahteraan Subyektif" dalam

Jurnal Psikologi, Vol.39 No. 1. Juni 2012 hal. 46-66

Vitterso, J., \& Nelsen, F., 2002." The conceptual and relational structure of subjective wellbeing, neurotism, and extraversion: once again, neurotism is the important predictor of happiness" dalam Social Indicators Research Dordrecht Vol. 57 No.1.89.

Wood, M.M \& Grenfeld, S.T., 1976, "Women Managers and Fear of Success" dalam Sex Roles Vol. 2 No. 4, 375-387.

Zuckerman, M. et.al, 1980, "Effect of Fear of Success on Intrinsic Motivation, Causal Attribution, and Choice Behavior" dalam Journal of Personality and Social Psychology Vol. 39 No. 3 p. 503-513 